Jurnal Kesehatan

Volume 11, Nomor 2, Tahun 2020

ISSN 2086-7751 (Print), ISSN 2548-5695 (Online)

http://ejurnal.poltekkes-tjk.ac.id/index.php/JK

\title{
Literature Review: Pengukuran Kesiapan Tenaga Kesehatan dalam Menerima Telehealth atau Telemedicine antara Negara Maju dan Negara Berkembang
}

\section{Literature Review: Readiness Assessment of Health Workers to Accept Telehealth and Telemedicine between Developed and Developing Countries}

\author{
Nadharuth Febrizhya Abigael ${ }^{1}$, Ernawaty ${ }^{2}$ \\ ${ }^{1,2}$ Fakultas Kesehatan Masyarakat, Universitas Airlangga, Indonesia
}

\section{ARTICLE INFO}

\section{Article history}

Received date

05 June 2020

Revised date

30 July 2020

03 August 2020

Accepted date

17 Sept 2020

\section{Keywords:}

E-health;

Telehealth;

Telemedicine.

Kata kunci:

E-health;

Telehealth;

Telemedicine.

\author{
ABSTRACT/ ABSTRAK
}

Telehealth and telemedicine become a necessity in health services amid technological advancements so that health services can reach the wider community to remote places. Implementing telehealth and telemedicine must be accompanied by the readiness of health workers to adapt to it. The purpose of this study is to determine the readiness of health workers in developed and developing countries and the barriers that affect the readiness of health workers. The research method is a literature review. Articles are chosen through google scholar, SAGE, JSTOR, and Science Direct with the keyword "ehealth readiness", "telehealth readiness", and "telemedicine readiness". From a total of 4783 articles, there were 56 articles selected based on abstracts and measurement targets and in the end, 18 articles were taken that were full text available for review. The most common dimensions to measure the readiness of healthcare on telehealth or telemedicine are core readiness, engagement readiness, and structural readiness. The implementation in a developed country is quite good based on core readiness and engagement readiness dimensions, but it needs more improvement in the structural readiness dimension, while in developing countries, there are already some countries that run it well but most are still constrained in infrastructure and resources financial. Overall, obstacles to running telehealth or telemedicine are also affected by the lack of available technological infrastructure in a country, lack of training of health workers, and lack of capacity building for health workers so that they are less able to adapt to telehealth and telemedicine.

Telehealth dan telemedicine menjadi sebuah kebutuhan dalam pelayanan kesehatan di tengah kemajuan teknologi sehingga pelayanan kesehatan dapat menjangkau masyarakat lebih luas hingga ke tempat yang terpencil. Pelaksanaan telehealth dan telemedicine harus disertai dengan kesiapan tenaga kesehatan dalam menerimanya. Tujuan penelitian untuk mengetahui kesiapan tenaga kesehatan di negara maju dan berkembang serta penghambat yang mempengaruhi kesiapan dari tenaga kesehatan itu sendiri. Metode dengan telaah literatur yang membahas tentang kesiapan tenaga kesehatan dalam menjalankan telehealth atau telemedicine dalam berbagai bentuk pelayanan melalui Google Scholar, SAGE, JSTOR dan Science Direct dengan kata kunci "e-health readiness", "telemedicine readiness", dan "telehealth readiness". Hasil dari 4783 artikel, 56 artikel yang diseleksi berdasarkan abstrak dan sasaran pengukuran yang akhirnya diambil 18 artikel yang tersedia full text untuk ditelaah. Dimensi yang paling umum digunakan untuk mengukur kesiapan tenaga kesehatan dalam mengimplementasikan telehealth atau telemedicine terdiri dari 3 yaitu core readiness, engagement readinessm dan structural readiness. Implementasi telehealth atau telemedicine di negara maju sudah cukup baik dilihat dari dimensi core readiness dan engagement readiness namun masih kurang baik pada dimensi structural readiness sedangkan di negara berkembang, beberapa negara sudah ada yang menjalankannya dengan baik tetapi sebagian besar masih terkendala secara infrastruktur dan dan sumber daya finansial. Secara keseluruhan, hambatan untuk menjalankan telehealth atau telemedicine juga dipengaruhi oleh kurang baiknya infratsruktur teknologi yang ada di suatu negara, kurangnya pelatihan kepada tenaga kesehatan, dan kurangnya capacity building bagi tenaga kesehatan sehingga mereka kurang dapat beradaptasi terhadap telehealth dan telemedicine.

Corresponding Author:

Nadharuth Febrizhya Abigael

Fakultas Kesehatan Masyarakat, Universitas Airlangga, Indonesia

Email: nadhapurba@gmail.com 



\section{PENDAHULUAN}

Kemajuan teknologi komunikasi dan informasi seperti komputer, internet atau telepon genggam telah merevolusi cara berkomunikasi yang dilakukan oleh masyarakat di seluruh dunia, baik di negara maju maupun berkembang (WHO, 2012). Akses, kesetaraan, kualitas, dan cost-effectiveness adalah masalah utama dalam kesehatan yang dapat diatasi salah satunya dengan keberadaan perkembangan teknologi komunikasi dan informasi (WHO, 2012). Pada tahun 2005, 192 negara anggota WHO bertemu di Geneva untuk membahas resolusi tentang $e$ health dan perannya yang berkontribusi dalam manajemen kesehatan serta perkembangan kesehatan masyarakat dimana menghasilkan kesepakatan akhir yang menetapkan bahwa $e$ health merupakan sebuah upaya mengoptimalkan penggunaan teknologi informasi dan komunikasi dalam mendukung aspek kesehatan seperti pelayanan kesehatan, surveilans kesehatan, literatur kesehatan, pendidikan kesehatan, pengembangan pendidikan dan juga penelitian kesehatan yang mampu menguatkan hak kemanusiaan yang fundamental melalui peningkatan kesetaraan, solidaritas, dan kualitas pelayanan (PAHO, 2016). Penerapan e-health dibagi menjadi beberapa komponen utama menurut R.E. Scott yaitu health informatics, telehealth and telemedicine, e-learning, dan electronic commerce (PAHO, 2016). Komponen utama dalam $e$-health yang akan dibahas lebih lanjut dalam artikel ini adalah telehealth and telemedicine.

Menurut WHO, telemedicine adalah pemberian pelayanan kesehatan yang dilakukan secara tidak langsung karena keterbatasan jarak oleh tenaga kesehatan dengan menggunakan teknologi informasi dan komunikasi untuk bertukar informasi tentang diagnosis, pengobatan, pencegahan penyakit, serta penelitian dan evaluasi untuk kelanjutan pembelajaran kesehatan (WHO, 2012). Telemedicine juga merupakan penggunaan komunikasi elektornik dan teknologi informasi untuk memberikan pelayanan klinis ketika tenaga kesehatan dan pasien berada di lokasi yang berbeda (American Telemedicne Assosiation, 2006). Istilah telemedicine juga berkaitan dengan istilah telehealth yang biasanya berhubungan dengan aplikasi yang mampu menjalankan pembelajaran jarak jauh, menjangkau pasien atau pelanggan, dan berbagai aktivitas yang dapat mendukung pelayanan kesehatan berupa videoconferencing, penyampaian gambar, data informasi pasien, pemantauan pasien jarak jauh, ataupun penyediaan pusat informasi perawatan (American Telemedicne Assosiation, 2006). Pengertian dari telemedicine dan telehealth yang sudah dijelaskan pada dasarnya merupakan dua istilah yang tidak dapat dipisahkan satu dengan yang lain karena saling berhubungan dan keberadaanya menjadi sebuah usaha untuk menyediakan hubungan komunikasi antara tenaga kesehatan dengan masyarakat secara lebih cepat (Ghani, et al., 2018).

Penerapan telemedicine atau telehealth tentu saja dipengaruhi oleh berbagai macam faktor untuk mengusahakan pelaksanaannya dapat berjalan dengan baik. Keuangan, keterampilan, dan budaya memegang peran utama dalam kesusksesan pelaksanaan telemedicine atau telehealth (Guitart-masip, et al, 2016). Di dalam pelaksanaannya, meskipun kecanggihan teknologi dilihat sebagai sebuah masa depan yang baik dalam pelayanan kesehatan, tetap saja masih sering terjadi kegagalan (Mauco, Scott, \& Mars, 2018). Kenyataannya, penggunaan teknologi dalam pelayanan kesehatan adalah sebuah perubahan yang besar dan perlu adanya adaptasi dan implementasi telemedicine atau telehealth tidak akan efektif apabila penyedia pelayanan kesehatan tidak siap dengan perubahan yang terjadi (Saleh, Khodor, Alameddine, \& Baroud, 2016). Implementasi dari telemedicine atau telehealth memang tidak mudah dan berdasarkan data yang ada tingkat kegagalan yang terjadi adalah sebesar $70 \%$ dimana faktor utamanya adalah bukan karena kegagalan dari teknologi nya melainkan karena kurangnya kesiapan dalam menggunakan teknologi yang ada (Mauco, et al., 2018).

Berdasarkan penelitian sebelumnya yang sudah dilakukan, sangat penting untuk menilai dan mengidentifikasi faktor penghambat dalam kelancaran pelaksanaan telemedicine atau telehealth dimana beberapa faktor penghambatnya adalah masalah waktu yang cukup lama dalam membuat janji untuk pemberian pelayanan antara tenaga kesehatan dengan pasien, sulitnya beradaptasi dengan satu tenaga kesehatan atau tenaga kesehatan yang berbeda-beda sehingga membuat pasien kebingungan, dan kesulitan dalam mengakses situs atau aplikasi yang digunakan untuk menjalankan telemendicine atau telehealth (Vahedi, 2017). Menurut Wade, penghalang yang sangat krusial dalam mempengaruhi implementasi telehealth adalah penerimaan dari tenaga kesehatan (Vahedi, 2017) sehingga sangat penting untuk dilakukan identifikasi terhadap faktor yang menghambat tenaga kesehatan dalam 
menerima pelaksanaan telehealth atau telemedicine.

Metode yang dilakukan dalam penelitian ini adalah telaah literatur yaitu dengan mengumpulkan artikel tentang kesiapan tenaga kesehatan dalam menerima atau menimplementasikan pelayanan kesehatan berbasis teknologi melalui telemedicine atau telehealth. Artikel yang ditinjau dalam pembahasan diterbitkan dari Januari 2015 hingga Desember 2019 dan ditemukan melalui pencarian berbasis komputer melalui Google Scholar, SAGE, JSTOR dan Science Direct dengan kata kunci "telemedicine readiness", "telehealth readiness", dan "e-health readiness". Artikel yang dipilih adalah artikel yang open-access dan membahas tentang penilaian kesiapan dalam telemedicine atau telehealth pada tenaga kesehatan dan tidak terbatas oleh artikel yang membuat instrumen penelitian tentang kesiapan pelaksanaan pelayanan kesehatan berbasis teknologi informasi dan komunikasi. Hasil pencarian dari berbagai database diperoleh 4783 artikel yang berkaitan dengan kata kunci, kemudian didapatkan 207 artikel setelah ditinjau berdasarkan judul, dan kemudian 56 artikel terpilih berdasarkan abstrak, tujuan dan sasaran pengukuran. Hasil dari 56 artikel, dipilih kembali artikel yang open-acces dan dapat mewakili pengukuran di setiap negara maju dan berkembang sehingga didapatkan 37 artikel yang pada akhirnya diambil 18 artikel untuk ditelaah. Keterangan lebih rinci dalam proses pemilihan artikel dapat dilihat pada Gambar 1.

Tujuan dari penelitian ini adalah untuk meninjau perbandingan kesiapan tenaga kesehatan antara negara maju dengan negara berkembang dalam menerima dan memberikan pelayanan kesehatan berbasis teknologi informasi dan komunikasi melalui telemedicine atau telehealth. Penjabaran kesiapan tenaga kesehatan ini berasal dari penelitian yang dilakukan di 12 negara yang berbeda dari negara maju yaitu Amerika Serikat, Austria, Australia, Brazil, Skotlandia dan dari negara berkembang yaitu Eutophia, Uganda, Afrika Selatan, Indonesia, Pakistan, Libyan, dan Lebanon sehingga bisa dilihat perbandingan antara negara maju dengan negara berkembang untuk kesiapan dan karakteristik tenaga kesehatannya serta hambatan yang dilalui dalam kesiapan menerima telemedicine atau telehealth di institusi masingmasing. Penelitian yang dilakukan di setiap negara adalah pengukuran kepada tenaga kesehatan baik yang ada di rumah sakit maupun klinik. Selain itu, penelitian ini akan menggambarkan aspek-aspek yang dapat menilai kesiapan tenaga kesehatan sehingga harapannya dapat menjadi pembelajaran bagi pemerintah, institusi, atau lembaga yang hendak melakukan persiapan terhadap pelaksanaan telemedicine atau telehealth di masa yang akan datang.

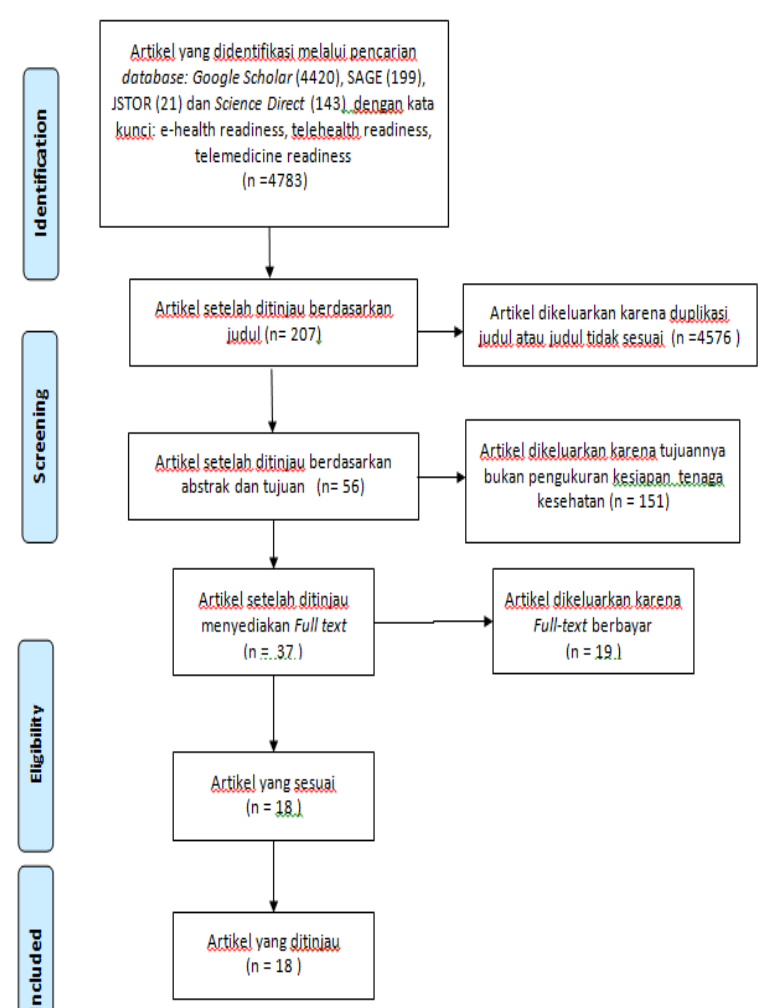

Gambar 1. Diagram Alur Proses Seleksi dan Pemilihan Artikel

\section{PEMBAHASAN}

\section{Dimensi Pengukuran Kesiapan}

Dalam menilai kesiapan teknologi informasi dan komunikasi dalam kesehatan, ada banyak faktor yang dipertimbangkan sesuai dengan kebutuhan penelitian. Dimensi yang paling umum digunakan dalam pengukuran kepada tenaga kesehatan secara umum adalah core readiness, engagement readiness, dan structural readiness (Jennett, et al., 2003). Namun selain itu, dimensi lain yang juga dapat diukur untuk menilai kesiapan adalah organizational readiness, technological/infrastructural readiness, societal readiness, government readiness, dan public/patient readiness (Mauco, et al., 2018). Dimensi yang digunakan tergantung dari target populasi penelitian maupun jenis pelayanan telehealth dan telemedicine yang berbeda-beda. Dimensi kesiapan yang diperjelas dalam artikel ini adalah 
tiga indikator dimensi yang paling umum yaitu core readiness, engagement readiness, dan struvtural readiness.

Menurut P Jennett et al., dimensi core readiness merupakan pengukuran kesiapan dalam menerima telehealth dan telemedicine sebagai sebuah kebutuhan dasar yang diungkapkan dengan kepuasan atau kekecewaan yang mendasar terhadap situasi dimana seseorang harus dihadapkan dengan perubahan mekanisme dan harus beradaptasi dengan perkembangan zaman (Jennett, et al., 2003). Dalam mengukur core readiness, petanyaan yang dapat digunakan adalah tentang kepuasan terhadap pemberian pelayanan yang dilakukan pada masa ini, pernah atau tidaknya mengalami situasi atau pengaruh buruk yang disebabkan karena tidak dapat menjangkau pelayanan kesehatan, dan kebutuhan untuk dapat melakukan pelayanan kesehatan jarak jauh kepada pasien atau masyarakat (Muigg, Kastner, Duftschmid, Modre-Osprian, \& Haluza, 2019).

Menurut Beebejaun \& Chittoo, engagement readiness adalah dimensi yang digunakan untuk mengukur pengetahuan tenaga kesehatan tentang mekanisme dan pelaksanaan teknologi kesehatan, mengukur seberapa besar manfaat atau kesulitan yang dapat dirasakan oleh tenaga keseahatan dengan menjalankan telehealth dan telemedicine serta keinginan dan kemauan tenaga kesehatan untuk mengikuti pelatihan berkelanjutan dalam rangka mengembangkan pengetahuan dan keterampilan tentang pelaksanaan teleheath dan telemedicine (Beebeejaun \& Chittoo, 2017). Dalam mengukur kesiapan melalui engagement, pertanyaan yang dapat diajukan adalah tentang ada atau tidaknya rasa ingin tahu yang lebih terhadap perkembangan pelayanan kesehatan melalui telemonitoring, keinginan untuk mengembangkan diri bersama dengan tenaga kesehatan lainnya dalam melakukan telehealth dan telemedicine, keterbukaan satu sama lain antara tenaga kesehatan tentang manfaat telehealth dan telemedicine, dan keinginan untuk menginvenstasikan lebih banyak waktu dalam melakukan telehealth dan telemedicine (Muigg, et al., 2019).

Dimensi structural readiness bisa juga dikaitkan dengan technology readiness karena menrurut Pujani, structural readiness berhubungan denga kesiapan teknologi yang tersedia berupa hardware, software, jaringan yang memadai dan kualitas serta kecepatan dari jaringan tersebut sehingga pelayanan dapat berjalan dengan baik (Pujani, 2018). Dalam mengukur structural readiness, dapat dilihat melalui ketersediaan akses 24 jam untuk dapat melakukan pelayanan, pengorganisasian jadwal yang tepat guna, kemampuan teknis tenaga kesehatan dalam melakukan pendekatan teknologi dengan baik, dan jenis pelayanan yang mudah diimplementasikan (Jennett, et al., 2003).

\section{Perbandingan Kesiapan Antar Negara}

Kesiapan tenaga kesehatan dalam menerima dan menjalankan telehelath dan telemedicine sudah banyak dilakukan di berbagai negara, baik negara maju maupun berkembang. Penilaian kesiapan tenaga kesehatan ini mencakup berbagai bentuk telemedicine dan telehealth seperti telemonitoring untuk diabetes, teleconsultation untuk anak-anak dan orang lanjut usia, teledentistry, dan penggunaan aplikasi e-health. Dalam pembahasan ini dianalisis kesiapan tenaga kesehatan dalam menerima telehealth dan telemedicine di negara maju dan negara berkembang. Kesiapan tenaga kesehatan di negara maju dianalisis melalui artikel dari penelitian di Amerika Serikat, Austria, Australia, Brazil, dan Skotlandia. Sedangkan, kesiapan tenaga kesehatan di negara berkembang dianalisis melalui artikel dari penelitian di Eutophia, Uganda, Afrika Selatan, Indonesia, Pakistan, Libyan, dan Lebanon.

\section{Negara Maju}

Pengukuran kesiapan di negara maju sebagian besar menggunakan dimensi core readiness, engagement readiness, dan structural readiness dalam analisis penelitiannya. Di Austria, penelitian kesiapan tenaga kesehatan dilakukan pada telemonitoring untuk penderita diabetes dengan hasil yang menunjukkan bahwa core readiness dan engagement readiness memiliki tingkat kesiapan yang sama yaitu sebesar $67,5 \%$ sedangkan structural readiness ada pada tingkat kesiapan 46,8\%. Kesiapan tenaga kesehatan di Austria untuk optimis terhadap telemonitoring adalah sebesar $61 \%$ (Muigg, et al., 2019). Selain itu, Austria juga memliki beberapa aplikasi medis yang biasa digunakan oleh tenaga kesehatan sehingga dilakukan penelitian yang mengukur kesiapan dalam menggunakan aplikasi medis yang menunjukkan hasil bahwa engagement readiness ada pada tingkat yang paling tinggi dengan mean 3,4 , dilanjutkan dengan core readiness dengan mean 3,2 dan terakhir adalah structural readiness dengan mean 3,0 (Hofer \& Haluza, 2019). Kesiapan dalam menggunakan aplikasi medis ini disebabkan karena setengah dari partisipan penelitian $(51,7 \% \%)$ adalah pengguna sehari-hari 
dari aplikasi yang memanfaatkannya untuk mendukung penilaian klinis $(95,4 \%)$ dan penggunaan aplikasi juga mudah dengan kecepatan jaringan yang baik dan kualitasnya yang baik. Adanya penerapan pelayanan kesehatan dengan telemedicine atau telehealth keberadaannya sangat penting di Austria karena tenaga kesehatan privat lebih banyak jumlahnya daripada panel doctors (Muigg, et al., 2019). Dilihat dari hasil peneltian yang telah dilakukan, tenaga kesehatan di Austria sudah cukup siap dalam menerima dan menghadapi telemedicine atau telehealth untuk memberikan pelayanan kesehatan. Tingkat kesiapan pada core readiness dan engagement readiness juga ditemukan sama tingginya pada penelitian yang dilakukan pada 13 tenaga kesehatan di Australia dengan presentase 92\% sedangkan structural readiness ada pada persentase $31 \%$ (Scharwz, Ward, \& Willcock, 2014). Kesiapan tenaga kesehatan dapat ditingkatkan dengan lebih optimal melalui pelatihan yang dilakukan secara rutin seperti penelitian di Amerika Serikat kepada teledentistry yang menunjukkan kenaikan pada kesiapan tenaga kesehatan (Nayar, McFarland, Chandak, \& Gupta, 2017). Penelitian pada teledentistry tersebut juga kurang lebih menghasilkan data yang sama bahwa core readiness dan engagement readiness lebih tinggi dibandingkan dengan structural readiness, namun ketika dilakukan pelatihan terhadap partisipan penelitian tentang penerapan teledentistry, structural readiness pada tenaga kesehatan meningkat dari mean 2,67 menjadi 3,11 dan core readiness dan engagement readiness pun mengalami peningkatan yang signifikan (Nayar, et al., 2017). Adanya telehealth dan telemedicine memang diinisiasi oleh negara maju berkat perkembangan teknologi yang mumpuni dan kemampuan serta kemauan yang besar dari setiap tenaga kesehatan yang ada (Abdulrahim, 2019). Brazil adalah salah satu negara yang pemerintahnya menginvestasikan perkembangan telehealth dengan implementasinya dilakukan secara nasional dan menyeluruh sampai pada kota-kota yang paling terpencil. Penelitian yang telah dilakukan di Brazil menyatakan bahwa $66,3 \%$ tenaga kesehatan puas dengan pelayanan kesehatan yang dilakukan dengan teleconsultation (Pessoa, et al., 2016). Kesiapan tenaga kesehatan di negara maju sudah cukup baik berdasarkan review yang dilakukan dari beberapa artikel penelitian di negara maju disebabkan oleh penerimaan yang sangat baik oleh sebagian besar tenaga kesehatannya (Levy, 2016), penerimaan yang cukup baik terhadap teknologi karena sebagian besar sudah berpengalaman dalam menggunakan komputer sebagai media interaksi dalam melakukan pekerjaan di bidangnya (Nayar, et al., 2017), dan dukungan pemerintah yang masif dalam pengembangan implementasi untuk telehealth dan telemedicine (Pessoa, et al., 2016). Kekurangan yang masih harus menjadi perhatian di sebagian besar negara maju adalah pada dimensi structural readiness yang masih rendah yang menunjukkan bahwa meskipun sudah berstatus negara maju, teknologi yang sudah canggih pun harus disesuaikan dengan kemampuan dari tenaga kesehatan sehingga dapat dijalankan dengan maksimal.

\section{Negara Berkembang}

Pengukuran kesiapan tenaga kesehatan di negara berkembang sebagian besar juga dilakukan dengan dimensi core readiness, engagement readiness, dan structural/technology readiness, sedangkan cara yang lain adalah dengan mengukur kesiapan negara secara keseluruhan dalam mengimplementasikan telehealth dan telemedicine. Di negara berkembang, meskipun implementasi telehealth dan telemedicine mayoritas belum dijadikan sebuah pertimbangan yang matang untuk melaksanakan pelayanan kesehatan (Abdulrahim, 2019), beberapa negara sudah menunjukkan kesiapan yang baik dalam menerima telehealth atau telemedicine untuk diimplementasikan secara berkelanjutan. Sesuai dengan hasil penelitian, Mauritius dan Lebanon adalah 2 negara berkembang dengan tenaga kesehatan yang siap menjalankan telehealth atau telemedicine. Penelitian di Mauritius menunjukkan nilai mean untuk kesiapan mengadaptasi $e$-health adalah 4,27 dengan skala 1-5 dimana mean 5 adalah tertinggi yang berarti Mauritius sangat siap untuk mengadaptasi e-health. Tingginya angka kesiapan di Mauritius karena pengalaman yang cukup baik oleh sebagian besar tenaga kesehatan dengan penggunaan komputer dan teknologi informasi yang sudah tersedia di pelayanan kesehatannya (Beebeejaun \& Chittoo, 2017). Demikian halnya dengan Lebanon, penelitian menunjukkan bahwa dokter, perawat dan tenaga kesehatan lain sudah siap dalam mengimplementasikan telemedicine dengan persentase $71,9 \%$ perawat dan $67,8 \%$ tenaga kesehatan lain mengoperasikan komputer dalam kegiatan dan aktivitas pekerjaan sehari-harinya. Tenaga kesehatan di Lebanon juga percaya bahwa mereka mendapatkan manfaat yang signifikan dari implementasi sistem eHealth dan mereka pun memiliki kemampuan untuk beradaptasi dengan sistem tersebut dengan baik (Saleh, et al., 2016). Di luar dari negara tersebut, 
masih ada negara yang secara organisasi dan kekuatan strukturalnya masih belum siap untuk melaksanakan atau mengimplementasikan telehealth atau telemedicine. Ketidaksiapan ditunjukkan oleh negara Libyan menurut penelitian yang dilakukan oleh Abdulrahim (2019) dimana sistem kesehatan di Libyan masih memiliki kelemahan pada kesadaran tenaga kesehatan terhadap perkembangan teknologi, kurang baik dalam penanganan keselamatan pasien, dan masih banyak terjadi kesalahan pada proses administrasi. Kesiapan tenaga kesehatan Libyan terhadap telemedicine yang paling tinggi adalah pada tenaga kesehatan konsultan dengan mean 3,65 dan terendah pada asisten dokter yaitu dengan mean 3,18 dimana penggunaan teknologi kesehatan melalui remote monitoring hanya $2 \%$ saja dan tidak ada sama sekali responden yang menggunakan video consultation (Abdulrahim, 2019). Penelitian di Uganda menunjukkan ketidaksiapan menerima telemedicine pada HealthCenter-IV yaitu fasilitas kesehatan yang berada pada daerah yang terpencil dimana hasil nya adalah bahwa tidak ada satu pun dokter yang siap untuk menghadapi telemedicine dan persentase untuk keseluruhan tenaga kesehatannya adalah sebesar $37,5 \%$ saja yang siap untuk mengimplementasikan telemedicine (Kiberu, Scott, \& Mars, 2019). Namun, penelitian lainnya yang dilakukan di Uganda menunjukkan hasil yang baik untuk Regional Referal Hospital (RRH) dan National Referal Hospital (NRH) dimana untuk kelompok yang masih belum terbiasa dengan telemedicine, dimensi kesiapan tertinggi ada pada learning readiness dengan persentase $93,5 \%$ dan keseluruhan presentase kesiapannya adalah 52\% (Kiberu, Scott, \& Mars, 2019). Ketidaksiapan juga terjadi di Pakistan dan Indonesia sebagai negara yang berkembang dimana pemerintah Pakistan belum siap dengan infrastruktur untuk menghubungkan informasi antar organisasi yang menjadi salah satu pendukung implementasi telemedicine (Qureshi, 2014) dan kesiapan tenaga kesehatan yang ada di Padang, Indonesia masih berada di bawah rata-rata dengan mean tertinggi hanya 0,35 pada dimensi societal readiness yaitu salah satu dimensi pengukuran yang digunakan untuk melihat kesiapan berkaitan dengan sosialbudaya masyarakat Indonesia (Pujani, 2018). Kesiapan tenaga kesehatan di negara berkembang untuk menerima telehealth dan telemedicine tidak bisa dipukul rata karena setiap negara memiliki kebutuhannya masing-masing terhadap pelayanan kesehatan berbasis teknologi informasi meskipun sebagian besar negara berkembang menghadapi masalah terhadap sumber daya finansial, infrastruktur, dan pengetahuan (Weldegebrial, 2017). Meskipun begitu, dengan adanya dukungan dan koordinasi yang baik antara pemerintah dan institusi kesehatan, beberapa negara mampu menjalankan telemedicine dalam beberapa aspek dan merasa siap untuk terus mempertahankan implementasi teleheath atau telemedicine dalam pengembangan pelayanan kesehatan.

Negara maju dan negara berkembang memiliki tingkat kesiapan yang berbeda-beda berdasarkan setiap indikator dimensi yang diukur. Dilihat secara keseluruhan berdasarkan hasil telaah dari beberapa artikel, negara maju sebagai negara yang dianggap lebih baik daripada negara berkembang belum tentu memiliki kesiapan yang lebih baik dari beberapa implementasi telehealth di negara berkembang. Adanya kesiapan yang lebih baik di negara berkembang disebabkan karena adanya kebutuhan yang lebih besar untuk mengimplementasikan telehealth atau telemedicine menyesuaikan dengan kondisi beberapa di negara berkembang yang memang harus mengushakan pemberian pelayanan kesehatan ke daerah yang lebih terpencil yang tidak terjangkau oleh tenaga kesehatan. Perbedaannya dengan negar maju adalah implementasi telehealth atau telemedicine sebagian besar untuk mempercepat proses pelayanan sehingga tingkat kepentingannya tidak memaksa tenaga kesehatan atau institusi untuk mengimplementasikannya secara maksimal.

\section{Penghambat Kesiapan Tenaga Kesehatan}

Berdasarkan hasil penelitian yang ditelaah, baik negara maju maupun negara berkembang menghadapi masalah yang berbedabeda terhadap kesiapan tenaga kesehatannya untuk mengimplementasikan telehealth dan telemedicine. Faktor penghambat yang terjadi di setiap negara memang tergantung dari karakteristik masing-masing negara, pada prinsipnya setiap negara menghadapi jenis masalah yang serupa sehingga dalam perjalanannya harus rutin dilakukan evaluasi dan perbandingan terhadap permasalahan kesiapan tenaga kesehatan lainnya di daerah atau tempat yang berbeda.

Penghambat dasar untuk mengimplementasikan telehealth dan telemedicine berdasarkan hasil telaah adalah infrasturktur teknologi dan jaringan yang belum sepenuhnya baik, seperti perlengkapan dan kebutuhan dasar untuk mendukung video consultation (Scharwz, et al., 2014), kegagalan koneksi internet yang 
membuat konsultasi menjadi terganggu (Levy, 2016), dan ketiadaan jaringan transmisi khusus antar organisasi untuk memudahkan komunikasi (Qureshi, 2014). Dukungan pemerintah sangat penting dalam pengembangan infrastruktur teknologi karena pemerintah mampu melakukan advokasi antar organisasi dan pemerintah juga yang tahu akan kebutuhan masyarakat di setiap daerah untuk menyesuaikannya dengan fasilitas dan infrastruktur yang akan dibangun (Weldegebrial, 2017). Ketidaksiapan infrastukstur teknologi akan mempengaruhi tenaga kesehatan sehingga tidak siap untuk menghadapi telehealth dan telemedicine karena implementasinya tidak akan berjalan dengan maksimal dan bahkan justru akan menambah beban bagi tenaga kesehatan itu sendiri (Abdulrahim, 2019).

Tidak adanya pelatihan awal atau pelatihan berkelanjutan juga dapat menjadi penghambat ketidaksiapan tenaga kesehatan dalam menghadapai telehealth dan telemedicine. Sesuai dengan penelitian di Amerika Serikat, terbukti pelatihan dapat meningkatkan kesiapan tenaga kesehatan secara signifikan terutama dalam aspek teknis yaitu untuk menjalankan teknologi yang tersedia di pelayanan kesehatan (Nayar, et al., 2017). Hal ini disebabkan juga karena kurang sadarnya tenaga kesehatan tentang pentingnya telehealth dan telemedicine dan apabila sudah sadar pun tetap tidak memiliki kemampuan IT yang memadai untuk siap secara penuh mengimplementasikan telehealth dan telemedicine (Kiberu, et al., 2019). Maka dari itu, dengan tidak adanya pengembangan kemampuan melalui pelatihan kepada tenaga kesehatan membuat infrastruktur yang baik pun akan menjadi percuma karena tidak maksimalnya kemampuan untuk menjalankan teknologi yang ada (Saleh et al., 2016).

Apabila tenaga kesehatan sudah memiliki kemampuan yang baik dan infrasturktur teknologi juga sudah mumpuni, faktor lain yang bisa menjadi penghambat kesiapan tenaga kesehatan adalah keinginan dari tenaga kesehatan itu sendiri untuk beradaptasi dengan telehealth dan telemedicine. Keinginan tenaga kesehatan dapat dipengaruhi oleh banyak hal, misalnya persepsi tenaga kesehatan bahwa dengan mengintegrasikan pelayanan kesehatan pada teknologi informasi akan membuat healthcare manager menggantikan tenaga kesehatannya dengan komputer sehingga mengurangi lapangan kerja (Levy, 2016). Selain itu, ada atau tidaknya keinginan untuk beradaptasi dengan telehealth dan telemedicine berhubungan dengan kebiasaan yang telah dilakukan oleh tenaga kesehatan bertahun-tahun sehingga perlu usaha yang lebih keras dan dibutuhkan adanya capacity building oleh pihak management sehingga mampu menumbuhkan budaya dan kebiasaan baru kepada tenaga kesehatan dalam rangka beradaptasi dengan perkembangan teknologi (Saleh, et al., 2016). Pada kenyataannya, untuk mewujudkan implementasi telehealth dan telemedicine dalam pelayanan kesehatan yang harus diadaptasikan bukan hanya sekedar infrasturktur, hardware, software, keterampilan dan pengetahuan tetapi juga perilaku, nilai manfaat bersamaan dengan adaptasi susunan sosial, politik, dan budaya (Qureshi, 2014).

\section{SIMPULAN}

Perkembangan teknologi informasi dan komunikasi membuat bidang kesehatan juga berkembang melalui pelayanan kesehatan berbasis teknologi dan informasi yang salah satunya diwujudkan dengan adanya telehealth dan telemedicine. Telehealth dan telemedicine adalah istilah yang tidak dapat dipisahkan satu dengan yang lain karena saling berhubungan dan keberadaannya menjadi sebuah usaha untuk menyediakan komunikasi antara tenaga kesehatan dengan pasien di tempat yang berbeda. Namun, dalam implementasi telehealth dan telemedicine dibutuhkan kesiapan yang baik oleh tenaga kesehatan yang menjalankannya. Kesiapan tenaga kesehatan di negara maju dan berkembang dipengaruhi oleh berbagai faktor yang berbeda sesuai dengan karakteristik dan kondisi negara masing-masing. Pengukuran kesiapan di negara maju sudah cukup baik pada dimensi core readiness dan engagement readiness sehingga masih kurang siap pada dimensi structural readiness yang mengacu pada kurang baiknya teknologi yang sudah ada digunakan secara maksimal oleh tenaga kesehatan. Berbeda halnya dengan negara berkembang, di beberapa negara sudah ada yang baik melaksanakan telemedicine atau telehealth karena dituntut oleh kebutuhan untuk memang menerapkan telemedicine agar akses kesehatan dapat diterima oleh daerah-daerah yang masih belum terjangkau tenaga kesehatan yang memadai naumun masih kurang siap dari segi infratstuktur yang dipengaruhi oleh keterbatasan dana dari pemerintah. Secara umum, penghambat yang mempengaruhi kesiapan tenaga kesehatan dalam menjalankan telehealth dan telemedicine adalah kurang memadainya infrastruktur teknologi sebagai pendukung kelangsungan telehelath dan telemedicine, kurangnya pelatihan yang dilakukan kepada tenaga kesehatan untuk 
menambah pengetahuan dan keterampilan dalam menggunakan teknologi informasi dan komunikasi di bidang kesehatannya masing-masing, dan kurangnya capacity building yang dilakukan oleh pemerintah atau management rumah sakit untuk

\section{DAFTAR PUSTAKA}

Abdulrahim, A. (2019). e-Health Systems Adoption and Telemedicine Readiness: Practitioner Perspective from Libyan Healthcare Sector A Thesis Submitted for the Degree of Doctor of Philosophy By Ali Abdullrahim College of Engineering, Design and Physical Sciences Brunel Univers. [Thesis]. London: Brunel University London.

American Telemedicne Assosiation. (2006). Telemedicine, Telehealth, and Health Information Technology. An ATA Issue Paper, (May), 1-13.

Beebeejaun, R., \& Chittoo, H. (2017). An Assessment of e-Health Readiness in the Public Health Sector of Mauritius International Journal of Sciences: An Assessment of e-Health Readiness in the Public Health Sector of Mauritius Mohammad Reza Beebeejaun a*, Hemant Chittoo b. International Journal of Sciences: Basic and Applied Research (IJSBAR), (August).

Ghani, M. K. A., Mostafa, S. A., Mustapha, A., Aman, H., Mohamed, M. A., \& Jaber, M. M. (2018). Investigating telemedicine approaches: A 10-country comparison. International Journal of Engineering and Technology(UAE), 7(3.20 Special Issue 20), 451-460.

https://doi.org/10.14419/ijet.v7i2.29.13797

Guitart-masip, M., Beierholm, U. R., Dolan, R., Duzel, E., \& Dayan, P. (2016). Telemedicine Acceptance and Implementation in Developing Countries: Benefits, Categories, and Barriers. Journal of Cognitive Neuroscience, 4(3), 1-6. https://doi.org/10.17795/rijm38332.

Hofer, F., \& Haluza, D. (2019). Are Austrian practitioners ready to use medical apps? Results of a validation study. BMC Medical Informatics and Decision Making, 19(1), 1-9. https://doi.org/10.1186/s12911-019-0811-2

Jennett, P., Jackson, A., Healy, T., Ho, K., Kazanjian, A., Woollard, R., ... Bates, J. (2003). A study of a rural community's readiness for telehealth. Journal of Telemedicine and Telecare, 9(5), 259-263. membantu tenaga kesehatan dalam beradaptasi dan memiliki keinginan untuk melakukan integrasi ke telehealth dan telemedicine dalam kehidupan sehari-hari.

https://doi.org/10.1258/135763303769211265

Kiberu, V. M., Scott, R. E., \& Mars, M. (2019). Assessing core, e-learning, clinical and technology readiness to integrate telemedicine at public health facilities in Uganda: A health facility - Based survey. BMC Health Services Research, 19(1), 1-11. https://doi.org/10.1186/s12913-019-4057-6

Kiberu, V. M., Scott, R. E., \& Mars, M. (2019). Assessment of health provider readiness for telemedicine services in Uganda. Health Information Management Journal, 48(1), 33-41.

https://doi.org/10.1177/1833358317749369

Levy, S. (2016). Staff perceptions of Telehealth Adoption: Lessons learned from Care at Home pilot in Scotland, 1-6. https://doi.org/10.14236/ewic/his2016.3

Mauco, K. L., Scott, R. E., \& Mars, M. (2018). Critical analysis of e-health readiness assessment frameworks: suitability for application in developing countries. Journal of Telemedicine and Telecare, 24(2), 110-117. https://doi.org/10.1177/1357633X16686548

Muigg, D., Kastner, P., Duftschmid, G., ModreOsprian, R., \& Haluza, D. (2019). Readiness to use telemonitoring in diabetes care: A cross-sectional study among Austrian practitioners. BMC Medical Informatics and Decision Making, 19(1), 1-10. https://doi.org/10.1186/s12911-019-0746-7

Nayar, P., McFarland, K. K., Chandak, A., \& Gupta, N. (2017). Readiness for Teledentistry: Validation of a Tool for Oral Health Professionals. Journal of Medical Systems, 4l(1). https://doi.org/10.1007/s10916-016-0654-7

PAHO. (2016). Framework for the Implementation of a Telemedicine Service. Pan American Organization, World Health Organization. www.paho.org/permissions

Pessoa, C., Sousa, L., Ribeiro, A., Oliveira, T., Silva, J. L., Alkmim, M. B., \& Marcolino, M. S. (2016). Description of factors related to the use of the teleconsultation system of a large telehealth service in Brazil-the telehealth network of Minas Gerais. Journal of the International Society for Telemedicine 
and EHealth, 4, e4-1.

Pujani, V. (2018). The Readiness Study of EHealth Adoption Among Regional Public Hospitals; An Empirical Study in Indonesia. International Journal of Health and Medical Sciences, 4(2), 40-47. https://doi.org/10.20469/ijhms.40002-2

Qureshi, Q. A. (2014). E-Readiness : a Critical Factor For Successful Implementation Of EHealth Projects in Developing Countries Like Pakistan. Gomal University Journal of Research, 30 (2), 30, 5-24. http://www.gujr.com.pk/index.php/GUJR/ar ticle/view/350/215

Saleh, S., Khodor, R., Alameddine, M., \& Baroud, M. (2016). Readiness of healthcare providers for eHealth: the case from primary healthcare centers in Lebanon. BMC Health Services Research, 16(1), 1-11. https://doi.org/10.1186/s12913-016-1896-2
Scharwz, F., Ward, J., \& Willcock, S. (2014). EHealth readiness in outback communities: An exploratory study. Rural and Remote Health, 14(3).

Vahedi, I. (2017). Application of Telehealth in the Practice, Upgrading of Knowledge, and Communication of Physicians with their Colleagues and Patients in Canada. [Thesis]. Canada: University of Victoria.

Weldegebrial, T. (2017). Telehealth in EthiopiaThe Barriers Vs The Success Factors Electronic Health Record \& Per.

WHO. (2012). Telemedicine: Opportunities and Developments in Member States: Report on the Second Global Survey on eHealth 2009 (Global Observatory for eHealth Series, Volume 2). Healthcare Informatics Research, 18(2), 153. https://doi.org/10.4258/hir.2012.18.2.153 